УДК 81.112

DOI: $10.33184 /$ bulletin-bsu-2021.4.39

\title{
К ВОПРОСУ ОБ ОПРЕДЕЛЕНИИ ПОНЯТИЯ «ГЕРМЕНЕВТИКА»
}

\author{
(C) Ю. А. Белова
}

Башкирский государственный университет

Россия, Республика Башкортостан, 450076 г. Уфа, ул. Коммунистическая, 19.

Тел.: +7 (347) 2732842 .

Email: julietta_belova@bk.ru

\begin{abstract}
История герменевтического знания ведет свое начало от Библии и становится методологической основой для многих наук, в т.ч. и для переводоведения. В статье подробно рассматриваются шесть этапов в развитии герменевтики как науки, связанной с интерпретацией и пониманием скрытых смыслов. В XVII в. герменевтика зародилась как теория библейского истолкования текстов, в XVIII в. она трактовалась как общая филологическая методология и наука в общелингвистическом понимании, позже стала методологической основой социально-гуманитарных наук, приобрела философскую направленность, что в настоящее время отразилось на ее определении как системы интерпретации для понимания образов и символов в текстах различной тематики.
\end{abstract}

Ключевые слова: герменевтика, герменевтическое знание, интерпретация, смысл.

На протяжении всей истории своего существования герменевтика рассматривалась как минимум с шести точек зрения, каждая из которых имеет право на самостоятельное существование. Как известно, герменевтика появилась как наука, занимающаяся истолкованием, интерпретацией текстов, но если рассматривать герменевтику и ее трактовки в хронологическом порядке, то можно говорить о следующих этапах в истории ее возникновения и существования: 1) теория библейского истолкования текстов, 2) общая филологическая методология, 3) наука в общелингвистическом понимании, 4) методологическая основа социальногуманитарных наук, 5) феноменология существования и экзистенциональное понимание, 6) система интерпретации для понимания образов и символов. Каждое из данных определений является не просто исторической вехой в развитии герменевтики, а целым направлением, системой знаний сквозь призму которых понятие герменевтики трансформируется, обрастая все новыми смыслами.

Самая распространенная и, пожалуй, наиболее древняя трактовка - это библейская герменевтика, т.е. наука об истолковании библейских текстов. Самое раннее упоминание герменевтики появилось в книге 1654 г. (J. C. Dannhauer "Hermeneutica sacra sive methodus exponendarum sacrarum litterarum"). Исходя из названия, герменевтика рассматривается не просто как хаотичное истолкование (экзегетика), а именно как методология интерпретации, т.е. это процесс, характеризующийся своими правилами и законами. После появления вышеуказанной книги, упоминание термина стало повсеместно встречаться в Германии и искусство толкования Священного писания в пользу правящих кругов становится просто необходимым, так как без благословления Церкви власть не могла воздействовать на массы. В период с 1720 по 1820 гг. каждый год появлялись все новые герменевтические пособия, изданные в помощь власть имущим. В Англии и Америке герменевтический подход также использовался при переводе библейских текстов, а позднее применялся к текстам других жанров, которые считались “obscure" (непонятными). К этой категории относились легенды, сказания, мифы и даже детские стишки. Таким образом, в английской традиции герменевтика применима к трудно интерпретируемым текстам различной тематики (юридическим, библейским, художественным), которые несут в себе символичный или иной смысл.

Кроме этого, библейские авторы использовали разные литературные жанры для того, чтобы донести истины Библии до массового читателя. Например, в православной традиции Евангелия воспринимается как «биография Иисуса», хотя в двух из них ничего не говорится о Рождестве, а из детства описано лишь одно событие. Значительная часть каждого из четырех Евангелий посвящена последней неделе земной жизни Христа. Это свидетельствует о том, что в Евангелиях факты были тщательно отобраны, чтобы наиболее ярко и четко донести благую весть Нового Завета. Также герменевтическая взаимосвязь прослеживается между Старым и Новым заветом. При сравнении Евангелия от Иоанна и от Павла многие ученые фиксируют различные системы понимания и интерпретации слов Иисуса. Таким образом, уже с древних времен формируется некий интерпретирующий принцип, который используется при написании текстов Писания. Например, в тексте выискиваются факты или свидетельства высоких моральных качеств последователей Иисуса и под этим углом зрения создается текст. В таком понимании «герменевтика» является системой для поиска скрытых смыслов текста.

В XVIII в. развитие рационализма как философского течения и возникновение классической филологии оказали значительное влияние на библейскую герменевтику. Появился историко-крити- 
ческий метод, который применяли в отношении не только библейских текстов, но и других жанров литературы. Считалось, что Библия должна быть интерпретирована по-новому, для рационально мыслящего просвещенного человека. Такой подход привел к «интеллектуализации» Библии, т.е. задача нового времени состояла в том, чтобы углубиться в текст, используя инструменты естественного разума, и найти высокие моральные истины, задуманные авторами Нового Завета, но скрытые в различных исторических терминах. Понятие «библейской герменевтики» было вытеснено герменевтикой, которая подчинялась правилам филологического истолкования не только библейских текстов, но и текстов общего пользования.

$\Phi$. Шлейермахер и его работы способствовали продвижению герменевтики в область искусства и науки уже в общелингвистическом понимании. Само определение герменевтики в «Академических речах», с которыми Ф. Шлейермахер выступал в 1829 г. в Прусской академии наук, сводится к следующему: герменевтика есть «понимание чужой речи». Данная концепция представляет собой особую ценность, т.к. впервые герменевтику как дисциплину сосредоточили на самом акте познания. Согласно теории Ф. Шлейермахера, любой «чужой» знак становится объектом интерпретации, а сам акт интерпретирования позволяет отличить истинный смысл от ложного и вынести суждение от тексте или событии [1].

Проблема, которая занимала ученого состояла в отношении между двумя формами интерпретации: «грамматической» и «технической». Это различие постоянно сохраняется на всем протяжении его работы, но его значение изменяется с годами. Грамматическая интерпретация основывается на конкретных характеристиках дискурса, общепринятых для данной культуры; техническая интерпретация обращается к единичности, даже гениальности, послания писателя. Данные интерпретации не могут быть осуществлены одновременно, хотя, по мнению автора, имеют одинаковый статус. Шлейермахер проясняет это следующим образом: рассматривать общий язык - значит забыть писателя; тогда как понять отдельного автора - значит забыть его язык, отвлечься от его конкретики. Либо мы воспринимаем общее, либо особенное. Первая интерпретация называется «объективной» и «негативной», поскольку, с одной стороны, имеет отношение к лингвистическим особенностям, отдельным от автора, но с другой - она просто показывает границы понимания; ее критическая ценность касается только ошибок в значениях слов. Вторая интерпретация называется «технической», и непосредственная задача герменевтики осуществляется благодаря этой второй интерпретации. Мы должны постичь субъективность говорящего, а о языке следует забыть. Эта интерпретация называется «пози- тивной», потому что она достигает того акта мышления, который породил дискурс [2].

Герменевтика как методологическая основа социально-гуманитарных наук рассматривалась в работах Вильгельма Дильтея, последователя $\Phi$. Шлейермахера и известного философа конца XIX в. Он считал, что именно герменевтика является центром, объединяющим дисциплины, связанные с искусством и литературой. Для интерпретации законов, литературных произведений или священного Писания требуется историческое понимание, операция, принципиально отличающаяся от научного подхода, так как в этом акте понимания в игру вступает личность человека, его знания и разум.

Преобразованные смыслы, нынешние ценности и отдаленные цели постоянно структурируют динамику жизни в соответствии с тремя временными измерениями прошлого, настоящего и будущего. Человек узнает о себе только посредством своих действий, направленности своей жизни наружу и воздействий, оказываемых ей на других. Он приходит к познанию себя только в обход понимания, которое, как и всегда, есть интерпретация. Любое общество создало свое собственное средство понимания путем создания социальных и культурных слов, которыми оно понимает себя. Всеобщая история, таким образом, становится областью герменевтики. Понять самого себя - значит сделать величайший обход через память, коротая сохраняет то, что стало значимым для всего человечества. Герменевтика - есть подъем от индивидуального до познания всеобщей истории, обобществление индивидуального [2].

Мартин Хайдеггер предпринял попытку исследовать существование человека в онтологическом смысле, и герменевтика стала трактоваться как феноменология существования и экзистенциональное понимание. Но при этом герменевтика не является наукой и не относится к правилам интерпретации текста, а есть феноменологическое понимание существования самого человека. По мнению ученого, понимание и интерпретация являются основными формами бытия, понять текст не значит найти безжизненный смысл, который в нем содержится, но раскрыть возможность бытия, на которое указывает текст.

Таким образом, герменевтика не рефлексия по поводу гуманитарных наук, но экспликация того онтологического основания, на котором эти науки могут быть выстроены. Вот утверждение, которое имеет для нас решающее значение: герменевтика «содержит корни того, что может быть названо „герменевтическим“ только в производном смысле, а именно, методологию гуманитарных наук» [3].

Ханс-Георг Гадамер, следуя идеям М. Хайдеггера, развил философскую герменевтику, в рамках которой он тщательно изучил работы В. Дильтея, $\Phi$. Шлейермахера и других. Герменевтика связана с эстетикой и философией исторического понимания, 
a также находит отражение в противоречивом утверждении лингвистики, что "being that can be understood is language" (понятое существование и есть язык). В конечном счете Гадамер утверждает лингвистический характер самой человеческой реальности, и герменевтика погружается в философские вопросы соотношения языка и бытия, понимания, истории и реальности. Герменевтика стоит в самом центре философских проблем, а понимание имеет эпистемологический и онтологический характер.

Герменевтику как систему интерпретирования ввел в употребление Поль Рикер. Это система правил, которая регулирует толкование конкретного текста или набора символов. Что интересно, он связал герменевтику и психоанализ, так как сон - это своего рода закодированный текст с элементами герменевтической ситуации и психоаналитик использует систему интерпретации для выявления скрытого смысла. Герменевтика - это процесс расшифровки, идущий от явного значения к неясному и завуалированному смыслу. Объектом интерпретации, то есть текстом в самом широком значении, могут быть символы и мифы в литературе, искусстве или в снах. Он проводит грань между явными и скрытыми символами, первые являются знаками с одним значением в символической логике, а другие и являются собственно герменевтическими.

Таким образом, рассмотрев основные этапы в развитии герменевтики, нужно отметить, что в современной науке герменевтика играет большую роль и элементы герменевтического знания проникают во всех сферы жизни общества. Перевод и переводоведение не являются исключением.

В книге «О переводе» в 2004 г. Поль Рикер говорит о переводе как о двусмысленном процессе, который в узком смысле характеризуется передачей словесного сообщения с одного языка на другой, а в широком смысле это - синоним интерпретации всей совокупности означающих внутри одной лингвистической общности [4].

Герменевтика внесла особый вклад в развитие переводоведения и перевода, который является и внутриязыковым (переименование и интерпретация знаков одного языка с помощью знаков другого языка) и межъязыковым явлением.

\section{ЛИТЕРАТУРА}

1. Schleirmaher F. Des differentes methodes du traduire / Trad. Antoine Berman. Paris: Seuil, 1999. P. 178.

2. Рикер П. Герменевтика и гуманитарные науки / пер. с англ. участников семинара по истории философии философского факультета НГУ / пер. выполнен по изданию: Paul Ricoeur. Hermeneutics and the Human Sciences. Essays on language, action and interpretation. Edited, translated and introduced by John B. Thomson. Cambridge: University Press, 1981. P. 43-62.

3. Хайдеггер М. Феноменологические интерпретации Аристотеля (Экспозиция герменевтической ситуации) / пер. с нем., предисл., науч. ред., сост. Н. А. Артеменко. СПб.: ИЦ «Гуманитарная Академия», 2012. 224 с.

4. Ricouer P. Sur la traduction. Paris: Bayard, 2004. P. 21

Поступила в редакичию 26.10.2021 2. 
DOI: 10.33184/bulletin-bsu-2021.4.39

\title{
TO DEFINING THE NOTION OF "HERMENEUTICS"
}

\author{
C) J. A. Belova \\ Bashkir State University \\ 19 Kommunisticheskaya Street, 450076 Ufa, Republic of Bashkortostan, Russia. \\ Phone: +7 (347) 2732842 . \\ Email: julietta_belova@bk.ru
}

The hermeneutic history originates from the texts of the Bible and becomes the methodological basis for many linguistic and non-linguistic sciences, the translation studies included. The author of the article studies in detail six stages of the development of hermeneutics. It is a science associated with the interpretation and understanding of hidden meanings and obscure sense. In the 17th century, hermeneutics originated as a theory of interpreting biblical texts; in the 18th century, it was defined as a general philological methodology and science from a linguistic viewpoint. It became known as an instrument for deciphering the sense of most of the texts existing at the time, namely, legends, myths, nursery rhymes, etc. Later it became the methodological basis for social sciences and humanities and headed for philosophy under F. Schleiermacher and M. Heidegger, which is now reflected in its definition. Thus, hermeneutics is a system of interpretation used to understand images and symbols in texts on various topics. Elements of hermeneutic knowledge penetrate into all spheres of society and translation, and translation studies are no exception. Paul Ricoeur speaks of translation as an ambiguous process, which in a narrow sense is characterized by the transfer of a verbal message from one language to another, and in a broad sense it is a synonym for the interpretation of the entire set of meanings within one linguistic community.

Keywords: hermeneutics, hermeneutic knowledge, interpretation, sense.

Published in Russian. Do not hesitate to contact us at bulletin_bsu@mail.ru if you need translation of the article.

\section{REFERENCES}

1. Schleirmaher F. Des differentes methodes du traduire / Trad. Antoine Berman. Paris: Seuil, 1999. Pp. 178.

2. Ricouer P. Germenevtika i gumanitarnye nauki / per. s angl. uchastnikov seminara po istorii filosofii filosofskogo fakul'teta NGU / per. vypolnen po izdaniyu: Paul Ricoeur. Hermeneutics and the Human Sciences.Essays on language, action and interpretation. Edited, translated and introduced by John B. Thomson. Cambridge: University Press, 1981. Pp. 43-62.

3. Heidegger M. Fenomenologicheskie interpretatsii Aristotelya (Ekspozitsiya germenevticheskoi situatsii) [Phenomenological interpretations of Aristotle (Exposition of the hermeneutic situation)] / per. s nem., predisl., nauch. red., sost. N. A. Artemenko. Saint Petersburg: ITs «Gumanitarnaya Akademiya», 2012.

4. Ricouer P. Sur la traduction. Paris: Bayard, 2004. Pp. 21. 